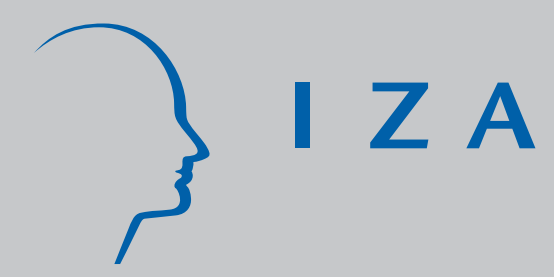

IZA DP No. 3431

Understanding Poverty among the Elderly in India: Implications for Social Pension Policy

Sarmistha Pal

Robert Palacios

April 2008 


\title{
Understanding Poverty among the Elderly in India: Implications for Social Pension Policy
}

\author{
Sarmistha Pal \\ CEDI, Brunel University \\ and IZA
}

Robert Palacios

World Bank

\author{
Discussion Paper No. 3431 \\ April 2008
}

IZA

P.O. Box 7240

53072 Bonn

Germany

Phone: +49-228-3894-0

Fax: +49-228-3894-180

E-mail: iza@iza.org

\begin{abstract}
Any opinions expressed here are those of the author(s) and not those of IZA. Research published in this series may include views on policy, but the institute itself takes no institutional policy positions.

The Institute for the Study of Labor (IZA) in Bonn is a local and virtual international research center and a place of communication between science, politics and business. IZA is an independent nonprofit organization supported by Deutsche Post World Net. The center is associated with the University of Bonn and offers a stimulating research environment through its international network, workshops and conferences, data service, project support, research visits and doctoral program. IZA engages in (i) original and internationally competitive research in all fields of labor economics, (ii) development of policy concepts, and (iii) dissemination of research results and concepts to the interested public.
\end{abstract}

IZA Discussion Papers often represent preliminary work and are circulated to encourage discussion. Citation of such a paper should account for its provisional character. A revised version may be available directly from the author. 
IZA Discussion Paper No. 3431

April 2008

\section{ABSTRACT \\ Understanding Poverty among the Elderly in India: Implications for Social Pension Policy*}

The Government of India is implementing a new policy which dramatically increases funding for a cash transfer program targeted to the poor elderly. The expansion of this 'social pension' in terms of coverage and benefit levels is taking place with little understanding of poverty among India's elderly or its determinants. This paper finds that households with elderly members do not have higher poverty rates than non-elderly households. This result is robust under various measures that take into account the size and composition of households. Separate evidence suggests that part of the explanation for this phenomenon is that the poor have higher mortality rates and are therefore underrepresented. This explanation has important implications for social pension policy and suggests that programs that reduce elderly mortality may actually increase the relative poverty levels of the elderly.

JEL Classification: J14, I31

Keywords: old age poverty, household demographic composition, adjusted poverty indices, elderly contribution, survivorship bias

Corresponding author:

Sarmistha Pal

Department of Economics and Finance

Brunel University

Uxbridge UB8 3PH

United Kingdom

E-mail: sarmistha.pal@brunel.ac.uk

\footnotetext{
* The views expressed here are those of the authors and do not represent those of the World Bank. Sarmistha Pal is particularly grateful to Angus Deaton, Jean Drèze and P.V. Srinivasan for their help with the methodology. We would also like to thank S. Irudaya Rajan, K. Subbarao, Puja Vasudeva Dutta and Sangeeta Goyal for their helpful comments on an earlier draft. Any errors are of course ours.
} 


\section{Understanding Poverty among the Elderly in India: Implications for Social Pension Policy}

\section{Introduction}

Cash transfers to the poor elderly or 'social pensions' are one of the most important antipoverty programs operating today in India. In 2007, the Government of India announced that changes to eligibility rules would increase the number of beneficiaries from an estimated 8.7 to almost 16 million people or roughly one in five elderly Indians. Moreover, the benefit provided by the central government would be more than doubled from 75 to 200 rupees per month. State governments would be asked to provide an additional 200 bringing the total to about 8.5 per cent of the rural poverty line ${ }^{1}$

Despite the priority that has been given to this type of categorical targeting, little is known about poverty among the elderly or its determinants and thus the potential impact of this important program. This paper seeks to inform the policy discussion by calculating and analyzing poverty rates for the elderly in India. The analysis is primarily based on the fifty-second round (1995-96) National Sample Survey (NSS) householdlevel data from the rural sector of sixteen major Indian states. This survey is especially suitable for the analysis of old age poverty since it includes additional information on members of the household aged 60 or above (see Pal, 2007 for further description of the data). We also make use of the more recent $60^{\text {th }}$ round (2004-05) NSS to update some of the results from the earlier survey. We focus on rural households where most of the poor elderly live and where there is generally very low coverage of contributory pension schemes.

\footnotetext{
${ }^{1}$ Based on the adjusted 2004-05 rural poverty line. See Goyal and Palacios (2008).
} 
This exercise updates the only previous study of old age poverty by Deaton and Paxson (1995) which was based on data for 1987-88 and covered six Indian states. Also, in order to arrive at more robust conclusions regarding poverty rates across demographic groups, we test for the sensitivity of the results to different plausible assumptions of adult equivalence and size economies in consumption.

The main conclusion of this analysis is that, with one important exception, there is no evidence that households with elderly members are more likely to be poor than non-elderly households. Although the result holds across states, there is variation that is suggestive of underlying demographic factors at work; in particular, a survivorship bias driven by higher mortality rates among the lifetime poor is detected. We test for this 'survivorship bias' in several ways (e.g., using various available data-sets) all of which support the hypothesis of higher mortality among the poor. The last section discusses the policy implications of this explanation of relative poverty rates, especially with regard to the provision of social pensions.

\section{Old Age Poverty in the Indian States}

The $52^{\text {nd }}$ round NSS provides a unique data-set for the analysis of elderly living conditions in the Indian states. It includes additional information on the elderly persons and contains information on their living arrangements, property/financial management and ownership etc. (for further details see Pal, 2004) that the usual round of NSS does not. Our analysis focuses on the extent of old age poverty in the rural sectors of sixteen major states of India. 
Columns 2-4 of Table 1 summarise the key demographic characteristics in the major Indian states in our sample. On average, about $27 \%$ of sample members coreside with elderly members though some inter-state disparity is observed. For example, while $43 \%$ individuals in Kerala live with an elderly person, the proportion is only $21 \%$ in AP and Tamil Nadu, 24\% in Rajasthan and West Bengal and 25\% in Assam, Bihar and MP, all below the national average. Clearly these states are at different stages of demographic development and an important correlate of this inter-state variation of key demographic characteristics would be variation in state-level prosperity.

\subsection{Unadjusted poverty estimates}

Following Deaton and Paxson (1995), our analysis of old age poverty classifies sample households by living arrangements; in particular, we distinguish between two groups of sample households - households with and without elderly people aged sixty and above. We further distinguish any elderly from older elderly often defined as those aged 75 and above. This distinction is particularly important because of deteriorating health and reduced productivity among the group of older elderly. Another factor that may justify this inquiry is the fact that widows tend to be overrepresented in the oldest cohorts. Finally, following the categorical targeting schemes in many states, we use a third classification, i.e., to distinguish between households with and without elderly 65+. 
We use average per capita monthly consumer expenditure (APCE) as an indicator of standard of living that is widely used in the literature. ${ }^{2}$ Official poverty measures in India are generally based on the household-level data collected by the Indian National Sample Survey Organisation (NSSO) going back to the early 1950's. A person is said to be poor if the average per capita (monthly) consumption expenditure (APCE) is below an officially constructed poverty line (corresponding to a per capita expenditure required to obtain the minimum caloric levels). Since APCE is household-specific, we shall first construct an indicator of household-level poverty head count ratio for households living with/without elderly members. Using the state-level poverty lines $z_{S},{ }^{3}$ we construct the poverty index for the s-th state $\mathrm{P}_{\mathrm{s} 0}, \mathrm{~s}=1,2, \ldots 16$ as follows:

$$
P_{s 0}=\frac{1}{n}\left(\frac{\sum_{i=1}^{q}\left(z_{s}-x_{s i}\right)}{z_{s}}\right)
$$

where $\mathrm{x}_{\mathrm{Si}}$ is the per capita expenditure of the $\mathrm{i}$-th household, $\mathrm{n}$ is the total number of individual members in a selected group of households (e.g., with/without elderly members) and $\mathrm{q}$ is the corresponding number of this group of household members who live below the poverty line. These poverty indices for households with and without elderly members are shown in Table 2B. In general, the HCR is lower in households with elderly members.

\footnotetext{
${ }^{2}$ Note that Appendix Table A1 summarises the state-level mean APCE (along with independent sample ttest for comparison of APCE) for households with and without elderly. Clearly the result varies with the definition of the elderly and also across the states.

${ }^{3}$ We take the official 1993-94 state-level poverty line estimates and adjust it by the 1995-96 state-level prices for agricultural labourers to obtain estimates of 1995-96 state-level poverty lines for the rural sectors of these states. Please note that 1993-94 poverty line estimates were not available for Jammu and Kashmir $(\mathrm{J} \& \mathrm{~K})$ and hence we were unable to calculate the poverty HCR for this state. Sarmistha Pal is particularly grateful to P.V. Srinivasan for his help with the calculation of poverty head count ratio.

${ }^{4}$ We could modify this equation to derive the poverty gap and the squared poverty gap indices.
} 
Deaton and Paxson (1995) adopted a slightly different procedure. They divided all household members into elderly (those who are above 60 years of age) and non-elderly (aged sixty or below). Then considering household-specific APCE as the individual consumption expenditure, they counted an individual specific poverty rate to be the proportion of people below an all-India poverty line for six large Indian states in 1987-88. Following Deaton and Paxson (1995), we also compute these individualspecific poverty head count ratios for elderly and non-elderly people in all the selected states (see column 2 of Table 2). In general, individual and household specific poverty head count ratios are comparable for 1995-96. It is however evident that compared to 1987-88, poverty rates are generally lower in 1995-96 for these six states studied by Deaton and Paxson (1995). In addition to economic growth over this period, the reduction of poverty over the period from $1987-88$ to $1995-96$, could possibly be attributed to the fact that our estimates use state-specific poverty lines while Deaton and Paxson use allIndia poverty lines for rural and urban areas. Both methods suffer from the limitation of not having data in the survey on intra-household allocation. ${ }^{5}$ The rest of our analysis is based on the household-level poverty rates, commonly used in most poverty studies.

We compare the poverty rates for households with and without elderly members and in this respect, highlight the similarities/differences in poverty rates among households living with various age/gender groups of elderly as defined above. First, we note that poverty rates for households with/without elderly $60+$ and $65+$ are rather

\footnotetext{
${ }^{5}$ There is some evidence that intra-household allocation may not favor the elderly. See, for example, Kochar (1999).
} 
comparable in most states. In general, unadjusted poverty rates tend to be lower for households with elderly in many states. The only clear exception is Kerala. ${ }^{6}$

We also consider poverty rates among households with female elderly: here the difference appears to be marginal when we compare households with any elderly 60+ with those with female elderly $60+$; however compared to poverty rates for older elderly $75+$ group, poverty rates among households with older female elderly aged $75+$ tend to be higher in many states. There are also pronounced inter-state variation in the poverty rates. For example, old age poverty rates tend to be lower in better performing states like Punjab, Haryana than in the worse performing ones (e.g., Bihar, Rajasthan).

Since the poverty rates shown in Table 2 are aggregate measures for each state, we cannot directly test whether the differences in poverty rates between households with and without elderly of any type $(60+, 65+75+)$ are statistically significant. Instead we consider the household level data and define a household to be poor if its average monthly per capital expenditure (APCE) is less than the state-level rural poverty line. This allows us to examine the average proportion (i.e. probability) of households living with/without elderly of a given category $(60+, 65+$ and $75+)$ to be poor. Results of this mean comparison as summarized in Table 3 shows similarity with our simple poverty HCR comparison discussed above. There is suggestion that households with elderly 60+ and $65+$ are significantly more likely to be poor only in Kerala while the reverse is true in Bihar, MP, Orissa, Punjab, UP and West Bengal. ${ }^{7}$ Even when we consider households with elderly $75+$, these households are significantly less likely to be poor in Bihar, Maharashtra, Orissa, Punjab and West Bengal while the difference is insignificant in

\footnotetext{
${ }^{6}$ Similar observation can also be made using alternative poverty indicators, e.g., see Appendix Table A2.

${ }^{7}$ Similar results are obtained using $60^{\text {th }}$ round NSS data; see Appendix Table A7.
} 
other states. Similar results are obtained when we consider households with and without elderly female $60+$ and $65+$ (see panel 2 of Table 3 ) while the result changes somewhat as we compare poverty likelihood among households with and without older female elderly $75+$ who tend to be worse off (relative all older elderly in our sample).

\subsection{Sensitivity of poverty estimates}

Our results presented in section 2.1 could however be somewhat misleading as these estimates, very much like the official poverty estimates in India, do not take account of the differences in household size or age/sex composition of household members. Taking these factors into account has been shown to affect the poverty rates among the elderly in other countries. ${ }^{8}$ This section will therefore examine the sensitivity of the poverty head count ratio to differences in age/sex composition of the household members as well as size economies in consumption.

A conventional way of addressing this difficulty is to make use of the equivalence scales that allow us to attach different weights to household members in different age/sex composition. Here we examine the sensitivity of the scale adjusted poverty rates to different choice of weights given to adult male and female (aged above 15 years) and children (aged less than 15 years) respectively: $(1,1,0.6),(1,0.8,0.6),(1,0.7,0.5) .{ }^{9}$ Our choice has been guided by the weights used by Dréze and Srinivasan (1997). Even when we consider the equivalence scale adjusted poverty estimates (as shown in Appendix Table A3), households with elderly tend to be worse of in most of the sample states,

\footnotetext{
${ }^{8}$ For a discussion of international evidence, see Palacios and Sluchynskyy (2006).

${ }^{9}$ Just to clarify, while the weight attached to adult male is taken to be 1 in each of these measures, that for adult female are 1, 0.8 and 0.7 respectively in these measures; similarly the weight attached to a child are considered to be $0.6,0.6$ and 0.5 .
} 
irrespective of choice of weights.

We next adjust the poverty rates for the variation in family size. The economies of scale adjusted per capita expenditure y for a household of size $\mathrm{n}$ is defined as: $y=\frac{Y}{n^{\theta}}$ where $\mathrm{Y}$ is the total household expenditure and $\theta$ is a parameter lying between 0 and 1 . If $\theta=1$, there are no economies of scale ( $\mathrm{y}$ is the per capita expenditure) and if $\theta=0, \mathrm{y}$ is the total household expenditure. The latter corresponds to the case of public goods where one person's consumption does not lower the consumption of others in the household. As before, following Dréze and Srinivasan (1997), we have considered 4 possible intermediate values of $\theta$, namely, $0.8,0.6,0.4$ and 0.2 where a weight of 0.2 would indicate higher size economies of consumption compared to 0.8 for example. A household of size $\mathrm{n}$ with total consumption $\mathrm{Y}$ is considered to be poor if $\mathrm{y}$ falls below a pre-specified threshold $\mathrm{z}^{\mathrm{S}}(\theta)$ for a given state $S=1,2, \ldots, \mathrm{K}$. For $\theta=1$, this is the conventional head-count ratio. However, we need some normalization rule to adjust $\mathrm{z}^{\mathrm{S}}(\theta)$ for the size economies of consumption. Following Drèze and Srinivasan (1997), we consider the following rule:

$$
z^{s}(\theta) \equiv z^{s}(1) m_{s}^{1-\theta}
$$

where $m_{S}$ is the average household size in a given state (see Table 1). This in turn implies that a household of average size in a given state is counted as 'poor' if and only if it has a per capita expenditure below $z^{S}(1)$ irrespective of the value of $\theta, S=1,2, \ldots K$. For consistency with the earlier calculations of HCR, we take $z^{S}(1)$ to be the state-specific poverty line expenses. 
Size adjusted HCR measures are shown in Appendix Table A4 for the two groups of elderly $60+$ and $75+$. While these estimates show sensitivity of poverty rates to choice of size economies in consumption (namely, $0.8,0.6,0.4$ and 0.2 ), poverty rates still tend to be generally lower among households with elderly members. Similarly, these adjusted poverty rate estimates as shown in panel 2 of Appendix Table A4 reiterate the initial observation (based on unadjusted poverty rates for this group) that households with older female elderly tend to be worse off in most states (relative to all older elderly).

Thus the preliminary conclusions drawn in section 2.1 hold: even after adjustment for equivalence scale and size economies in consumption, households with any elderly tend to better off while households although the sub-category of older female elderly tend to be worse off in some states.

\section{What Explains Low Relative Poverty Rates among the Elderly?}

The central finding of the last section was that in almost every Indian state, households with elderly members are either just as likely or even less likely to live in poor households relative to households without elderly members. These results reinforce those found by Deaton and Paxson using data for the late 1980s. While similar results

have been found in other countries, the global pattern is mixed. ${ }^{10}$ In middle and higher income countries, part of the explanation may be found in the extent of pension schemes mandated by the government. This is clearly not the case in rural India. What then would explain this pattern?

\footnotetext{
${ }^{10}$ See Whitehouse (200x).
} 


\subsection{Demographic composition of households with elderly}

Our results in section 2 do not appear to support categorical targeting of anti-poverty programmes on the elderly. In order to better understand this finding, let us start by comparing the demographic composition of these two groups of households, households with and without elderly members (all elderly 60+ and older elderly 75+). Table 4 suggests that the sample households differ significantly in terms of family size, dependency ratio and also the labor market participation rates of the elderly. Dependency ratio is defined here as the ratio of dependent to independent members of a household. While dependent members of a household are those children aged 0-14 years and also the elderly adults aged 75-99 years (who are less likely to contribute to family earnings), independent members of the households are those adults aged 15-74 years primarily contributing to family earnings. ${ }^{11}$ Average demographic characteristics of a household, namely, family size, dependency ratio and current elderly participation rates for households with and without elderly members (60+ and 75+) are summarised in Table 4. We also compute the independent sample t-statistics for comparison of means of household size and dependency ratio between these two groups of households (with and without elderly $60+$ as well as $75+$ ). Generally, average family size is higher among households with elderly (both $60+$ and $75+$ ) compared to those without elderly. However, current economic participation rates are lower among households with older elderly (75+), which in turn reflects a higher dependency ratio among households with older elderly group. Even after we control for household demographic composition, households with elderly are likely to be less poor (e.g., see Appendix Table A5). It is then

\footnotetext{
${ }^{11}$ Alternatively, we construct a second measure of dependency ratio: dependents are those aged 0-14 years and 60-99 years while independents are those aged 15-59 years.
} 
surprising that the poverty rates among households with elderly, especially those with older elderly, are lower and not higher.

\subsection{Missing elderly and the Kerala exception}

The one exception to our main result is the state of Kerala. This is clear from Tables 3 and also Appendix Table A5, which show that the poverty rate and the probability of being poor are both higher among elderly households. What clues does the Kerala exception provide?

Kerala is special in many ways ranking at or near the top among Indian states on many education and health indices. Social security coverage (including old age pensions) is higher than in other states due to the prevalence of dozens of state-subsidized 'welfare funds' ${ }^{12}$ It is one of only two states where the Communist party has dominated for decades and has a heterogeneous religious composition unique in India. Huge remittances from migrants working in the Gulf countries have contributed to growth and helped reduce poverty rates to one of the lowest among the large states. Most importantly for our purposes however, Kerala is much further ahead in its demographic transition and aging process than any other state in our sample. ${ }^{13}$

As in other countries, the rapid aging of Kerala's population is due to a large decline in fertility as well as longer adult life expectancy (see Table 1). Both developments could affect relative poverty among population sub-groups in several ways. For example, lower fertility would tend to reduce the dependency ratios of households

\footnotetext{
${ }^{12}$ See NCEUS (2006).

${ }^{13}$ See Zachariah and Rajan (1997)
} 
without elderly and raise their per capita expenditure levels. Other things constant, this could reduce poverty rates in favor of non-elderly households.

Another possibility is that by reducing mortality for lower income households in general, the number of poor individuals that live to old age increases. According to this hypothesis, one of the explanations for the observed patterns of relative poverty across states is that the poor die earlier and are therefore 'missing' from the poor households. If egalitarian social policies in Kerala have reduced the mortality of the poor, the survivorship bias may be less important there than in other states. In other words, the fact that elderly are more likely to be poor in Kerala than in other states could be because the lifetime poor are more likely to survive to old age. Surprisingly then, higher relative poverty among the elderly would imply success rather than failure. Unfortunately, data are not available for samples large enough to compare state-level mortality rates for the elderly by consumption class in order to test the specific hypothesis for Kerala.

\subsection{Evidence of Survivorship Bias}

However, the broader point - that relative old age poverty can partly be attributed to income-mortality differentials - can be tested in several ways. Most of the studies linking mortality and income levels have used data from higher income countries. ${ }^{14}$ These studies have generally found that a link does exist with implications for issues such as savings behavior and the design of pension schemes. The relevance of studies focusing on middle and high income countries to the situation in rural India is limited for a variety or reasons.

\footnotetext{
14 For a review, see Cutler et. al. (2006).
} 
In contrast, a study by Bannerjee and Duflo (2007) focus on the poor elderly in a number of developing countries. The authors start by pointing out that the demographic pyramid for low income households tended to include a higher proportion of elderly for higher income groups. This result held in nine out of 15 countries with only two countries exhibiting the opposite pattern. ${ }^{15}$

Using our NSS data $\left(60^{\text {th }}\right.$ round), we show a similar pattern in Table A6. So, for example, the share of total elderly to all adults rises from 18.5 per cent for the lowest quintile to 25.4 per cent in the highest quintile. Similarly, the ratio of persons aged 55+ in the highest decile is 46.9 compared to 27.3 per cent in the lowest decile. ${ }^{16}$

Bannerjee and Duflo next took advantage of a question that is included in household surveys in 11 developing countries that asks whether the respondent's parents are alive. The results were mixed but generally supported an income-mortality differential.

In a similar exercise, we tested data from a special survey commissioned by the Asian Development Bank and conducted in 2004. The national representative sample size included more than 40,000 Indian workers. The survey included a question on whether the respondent's father was still alive. After controlling for the age of the respondent, a probit regression was run to determine whether the probability that the father was still alive was correlated to income. As shown in column (2), Table 5, the log of income was positively and significantly correlated to the probability that the father was alive, further supporting the income-mortality relationship.

\footnotetext{
${ }^{15}$ In one of the two countries, South Africa, the results are almost certainly distorted by the presence of a very large social pension scheme.

${ }^{16}$ Similar trend is observed in $52^{\text {nd }}$ round NSS data.
} 
The strongest evidence from Bannerjee and Duflo comes from panel data for Indonesia and Vietnam. The authors confirmed a strong link between mortality and income level with the strongest relationship for individuals above age 50 . In rural Indonesia, a poor person over age 50 living in a rural area was five times more likely to have died in the next five years than a similar non-poor individual. A similar comparison showed triple the mortality rates in Vietnam among the poorest.

Panel data sets of this type are rarely available and we were not able to apply this methodology in the case of rural India. However, we were able to take advantage of the fact that the $60^{\text {th }}$ round NSS reports the age and sex of those who died in the past year. ${ }^{17}$ We use this information to select households with members aged 55+ and trace if any member aged 55+ died in these households in the past year. ${ }^{18}$ Amongst these households, we then adjusted their total per capita monthly expenditure (apce) to obtain the adjusted apce if these individuals had not died (i.e., household size + no of dead 55 during the previous year). We also adjust the total number of elderly $55+$ in these households assuming if these elderly were alive.

Next, we use a probit model to determine the probability that a member aged $55+$ dies in the past year considering the log of adjusted apce, sex of the deceased and other variables. Results as shown in column (1) of Table 5 yield a negative and statistically significant coefficient for the consumption variable apce. In other words, higher expenditure per capita is associated with lower mortality for members 55+ (also see figure 2).

\footnotetext{
${ }^{17}$ Note that this information was not available in the $52^{\text {nd }}$ round NSS.

${ }^{18}$ Given that age at death is available only for the members who died in the past year, we attempted to include as much information as possible. This induced us to focus on the probability of dying at or above 55 years among the households with a member aged 55+. This was further justified by the fact that the probability of death falls sharply (by about $15 \%$ ) if we instead considered households with elderly $60+$.
} 
The implication is that as incomes and expenditure levels rise, elderly mortality would decline and this effect would be greater among poorer households. This suggests that poorer areas of the country would tend to have lower elderly poverty relative to nonelderly poverty. In a final test, we use district-level $52^{\text {nd }}$ round NSS data to examine the effect of apce on relative poverty of the elderly defined as the ratio of hcr for households with elderly $60+$ to that of households without elderly $60+$. As expected, elderly poverty was lower (relative to non-elderly poverty) in districts with lower average per capita expenditure. The results, reported in column (3) of Table 5, further support the explanation for the observed differences in poverty rates between households with and without elderly.

Taken together then, there is evidence that at least part of the explanation for the observed relative poverty differences between households with and without elderly members is due to the fact that the poor elderly are 'missing' due to their higher mortality rates. As discussed below, this explanation has policy implications including how we look at categorical targeting of cash transfers to the elderly.

Figure 3 plots the predicted male and female 55+ mortality rates as well as those in the bottom decile of the distribution of apce (using estimates shown in column (2) of Table 5). This clearly highlights that the survivorship bias in our sample is driven by the mortality difference of poor and non-poor male elderly 55+ while the mortality difference among poor and non-poor female elderly is rather marginal. The latter could perhaps explain as to why households with older female elderly $75+$ tend to be worse off in a number of states (e.g., see Table 2). 


\section{Policy implications}

Our analysis has shown that poverty rates among the elderly in India are similar or lower than poverty rates among those living in non-elderly households. The single clear exception to this pattern is the demographically advanced state of Kerala. The interpretation of this finding is important; if a high relative poverty rate of the old is due to consumption-mortality differentials and a survivorship bias, then observed relative poverty rates may not be a good yardstick for assessing whether the elderly are a good candidate for categorical targeting.

The admittedly scarce international evidence as well as the evidence presented in this paper for India, supports the survivorship bias hypothesis. What are the implications of these findings? First, it suggests that changes in policy or circumstances that lead to higher survival rates among the poor elderly may, paradoxically, increase poverty among the old relative to other groups. This happens because the old are alive to be counted in the denominator and this generally reduces per capita income. ${ }^{19}$ Economic growth, higher remittances, better health care or an increase in social pension benefits could all improve the chances that the poor survive to old age and therefore, could increase the proportion and number of poor elderly. Given this counterintuitive result, it may be better to focus on other indicators such as mortality and morbidity rates of the elderly when assessing the impact of different policies and programs.

\footnotetext{
${ }^{19}$ A similar point has been made with regard to increased survival rates of children by Acemoglu and Johnson (2005).
} 
The increased dependency rate of poor households could have important effects on the consumption of the rest of the members of the household. This could be offset to the extent that the elderly are contributing to the overall income of the household. However, the data suggest that this contribution is relatively small in poor households with elderly. Moreover, the impact of mortality reducing income gains or health services is most likely to occur among individuals that are weak or sick and therefore less productive.

The results also have implications for pension policy. If the pattern observed in Kerala is replayed in other states as they pass through their own demographic transitions, the proportion of the poor that are elderly will increase, as will the costs of the social pension program. It would also increase the dependency ratio of poor households. Of course, this could be offset by a decline in absolute poverty rates that often accompanies the aging process as well as an expansion (albeit very gradual) in the role of contributory pension systems.

The evidence of an income-mortality link should also influence thinking about social pension design. Advocates of universal pensions ${ }^{20}$ that are paid to all citizens above a certain age, as in neighboring Nepal, must justify a much more regressive transfer than would have been the case if this link did not exist. Simply put, the rich would receive such a transfer for much longer than the poor. ${ }^{21}$ In contrast, well targeted schemes with lower initial eligibility ages could pay higher benefits to more poor elderly.

In this context, the recent initiatives by the Government of India to dramatically expand its social pension program provide a unique opportunity to assess the efficacy of

\footnotetext{
${ }^{20}$ See for example, Willmore (200x) and HelpAge International (2006).

${ }^{21}$ The Nepali case is especially relevant since the eligibility age for the universal benefit is set at 75, partly due to the limited budget and the need to pay all citizens that meet the age requirement.
} 
social pensions as well as behavioral reactions within households. ${ }^{22}$ Much depends, of course, on implementation of the schemes and their ability to deliver benefits to the poor. ${ }^{23}$ Surprisingly, the success of this initiative may actually increase elderly poverty rates by reducing the mortality of the target population.

\footnotetext{
${ }^{22}$ Another program, the Rashtriya Swasthya Bima Yojana health insurance scheme targeted to households below poverty level regardless of age or pre-existing conditions, may also result in an increase in elderly poverty rates by reducing mortality rates.

${ }^{23}$ For detailed analysis of social pensions in the states of Rajasthan and Karnataka see Vasudeva (2008) and Murgai (2008).
} 


\section{References}

Alam, M. 2004. 'Ageing, Old Age Income Security and Reforms: An exploration of Indian

Situation', in Economic and Political Weekly, August 14, 2004, pp. 3731-3740.

Bannerjee, A. and E. Duflo 2007 'Aging and Death under a Dollar a Day', mimeo, MIT.

Barrientos, A, M. Gorman and A. Heslop. 2003. 'Old Age Poverty in Developing Countries: Contributions and Dependence in Later Life', World Development 31(3), pp. 555-70.

Cutler, D., A. Deaton and A. Lleras-Muney 2006. 'The Determinants of Mortality', NBER working paper no. 11963, Cambridge, Massachusetts.

Deaton, A. and C. Paxson. 1995. 'Measuring Poverty among the Elderly', NBER working paper no. 5296, Cambridge, Massachusetts.

Deaton, A. and C. Paxson. 1998. 'Economies of Scale, Household Size and the Demand for Food', Journal of Political Economy, 106, pp. 898-930.

Drèze, J. and P.V. Srinivasan. 1997. 'Widowhood and Poverty in Rural India: Some Inferences from Household Survey Data', Journal of Development Economics 54, pp. 217-34.

Ghosh, S and S. Pal. 2004. 'The Effect of Inequality on Growth: Theory and Evidence from the Indian States', Review of Development Economics, 2004, February 8(1).

HelpAge India 2003. 'Non-contributory pension in India: A case study of Uttar Pradesh', Research and Development Division, HelpAge India, New Delhi, June 2003.

HelpAge International 2006. 'The need for social pensions',

Kakwani, N, K. Subbarao and A. Schwarz.2004. 'Living Conditions of Elderly in Africa and the Role of Social Protection, mimeo, World Bank.

Knodel, J. N. Chayovan and S. Siriboon. 1992. 'The Impact of Fertility Decline on Familial Support for the Elderly: An Illustration from Thailand', Population and Development Review 18(1): 79-103.

Kochar 1999. "Evaluating Familial Support for the Elderly: The Intrahousehold Allocation of Medical Expenditures", Economic Development and Cultural Change, The University of Chicago.

Murgai, R. 2008. 'Social Pensions in Karnataka', forthcoming as World Bank Pension Reform Primer working paper.

Pal, S. 2007. 'Intergenerational Transfers and Elderly Coresidence with Adult Children in Rural India', discussion paper IZA, University of Bonn, Germany.

Palacios, R. 2006, "Expanding Pension Coverage to the Informal Sector", mimeo World Bank.

Palacios R. and O. Sluchynsky 2006. "The role of social pensions", Pension Reform Primer working paper series, World Bank.

Prakash, I. 1999. 'Ageing in India', paper prepared for World Health Organization.

Rajan, S.I., U.S. Mishra and P.S. Sharma. 1999. Indian's Elderly: Burden or Challenge?' Sage Publications, New Delhi. 
Subbarao, K. 2005. 'Aging and Poverty in Africa and the Role of Social Pensions', mimeo, World Bank.

Vasudeva-Dutta, P. (2008) 'Social Pensions in Rajasthan', forthcoming as World Bank Pension Reform Primer working paper.

Visaria, P. 1998. 'Demographics of Ageing in India: An Abstract', www.iief.com/paper/pravinvisaria.pdf.

Willmore L. 2007. 'Universal Pensions for Developing Countries', World Development vol. 35, number 1, pp. 24-51.

World Bank. 2001. 'India: The Challenge of Old Age Income Security', Report No. 22034-IN, Finance and Private Sector Development Division, South Asia Region, Washington D.C.

Zachariah C. and S.I. Rajan 1997 'Kerala's Demographic Transition: Causes and Consequences', Sage Publications, New Delhi.

Zimmer, Z. and J. Kwong. 2003. 'Family Size and Support of Older Adults in Urban and Rural China: Current Effects and Future Implications', Demography 40(1): 23-44.

Zimmer, Z., J. Knodel, K.S. Kim and S. Puch. 2006. 'The Impact of Past Conflicts on the Elderly in Cambodia', Population and Development Review 32(2): 333-36. 
Table 1. Selected state characteristics

\begin{tabular}{|c|c|c|c|c|c|c|c|c|c|}
\hline \multirow[b]{2}{*}{ States } & \multicolumn{2}{|l|}{ (1) } & \multicolumn{2}{|l|}{ (2) } & \multicolumn{4}{|l|}{ (3) } & \multirow{2}{*}{$\begin{array}{l}\text { (4) } \\
\text { Life } \\
\text { expectancy } \\
(1991)\end{array}$} \\
\hline & $\begin{array}{l}\text { Current } \\
\text { pension[1] } \\
\text { (Rs/ month) }\end{array}$ & $\begin{array}{l}\text { Min. age of } \\
\text { eligibility } \\
\text { (years) [1] }\end{array}$ & $\begin{array}{l}\text { Living } \\
\text { with old } \\
>=60\end{array}$ & $\begin{array}{l}\text { Total } \\
\text { hholds }\end{array}$ & $\begin{array}{l}\text { Total popn } \\
\text { [2] }\end{array}$ & $\begin{array}{l}\text { living } \\
\text { with old } \\
60+ \\
\end{array}$ & $\begin{array}{l}\text { Living } \\
\text { with old } \\
75+ \\
\end{array}$ & $\begin{array}{l}\text { living with } \\
\text { female } \\
\text { elderly } 60_{+}\end{array}$ & \\
\hline $\mathrm{AP}$ & 75 & 65 & 0.19 & 4957 & 22705 & 0.21 & 0.031 & 0.12 & 63.1 \\
\hline Assam & 60 & $\begin{array}{l}65 \text { (male), } \\
60 \text { (female) }\end{array}$ & 0.20 & 3287 & 17452 & 0.26 & 0.034 & 0.127 & 57.2 \\
\hline Bihar & 100 & 60 & 0.21 & 6668 & 38819 & 0.26 & 0.053 & 0.162 & 60.2 \\
\hline Gujarat & $\begin{array}{l}100, \\
275\end{array}$ & $\begin{array}{l}60-65 \\
65+\end{array}$ & 0.23 & 2494 & 13710 & 0.25 & 0.055 & 0.171 & 62.5 \\
\hline Haryana & 100 & 60 & 0.27 & 1065 & 6272 & 0.31 & 0.085 & 0.214 & 64.5 \\
\hline Karanataka & 100 & 65 & 0.24 & 2558 & 14366 & 0.30 & 0.056 & 0.183 & 64.0 \\
\hline Kerala & 110 & 65 & 0.37 & 2850 & 13990 & 0.43 & 0.11 & 0.282 & 73.5 \\
\hline $\mathrm{MP}$ & 150 & $\begin{array}{l}60 \text { (male) } \\
50 \text { (female) }\end{array}$ & 0.21 & 5161 & 28822 & 0.26 & 0.053 & 0.171 & 56.4 \\
\hline Maharashtra & 100 & $\begin{array}{l}65(\text { male }) \\
60 \text { (female) }\end{array}$ & 0.30 & 4286 & 22458 & 0.34 & 0.068 & 0.216 & 65.8 \\
\hline Orissa & 100 & 65 & 0.26 & 3219 & 16301 & 0.32 & 0.07 & 0.187 & 57.7 \\
\hline Punjab & 200 & $\begin{array}{l}65 \text { (male) } \\
60 \text { (female) }\end{array}$ & 0.25 & 2227 & 12592 & 0.30 & 0.091 & 0.204 & 68.1 \\
\hline Rajasthan & $\begin{array}{l}200 \\
300\end{array}$ & $\begin{array}{l}58 \text { (male) } \\
55 \text { (female) }\end{array}$ & 0.20 & 3112 & 17594 & 0.24 & 0.057 & 0.167 & 60.5 \\
\hline Tamilnadu & 150 & 60 & 0.19 & 4238 & 17856 & 0.21 & 0.042 & 0.107 & 64.6 \\
\hline UP & 125 & 60 & 0.28 & 8651 & 52292 & 0.33 & 0.078 & 0.013 & 58.4 \\
\hline WB & 300 & 60 & 0.20 & 4612 & 24095 & 0.24 & 0.045 & 0.48 & 63.4 \\
\hline All India [3] & - & - & 0.23 & 71284 & 380885 & 0.27 & 0.062 & & 62.5 \\
\hline
\end{tabular}

Note:[1] Source: Help Age India: http://www.helpageindia.org/scg2.php. [2] This is simply the sum of all household members in a state.

[3] $52^{\text {nd }}$ round NSS also includes households from other Indian states as well. 
TABLE 2. Unadjusted household and individual level rural poverty head-count ratio

\begin{tabular}{|c|c|c|c|c|c|c|c|c|c|c|}
\hline & (1) Poverty & $\mathrm{RR}$ for house & lds with & & & & $\begin{array}{l}\text { (2) Individ } \\
\text { her }\end{array}$ & & $\begin{array}{l}\text { (3)Poverty } \mathrm{F} \\
\text { households }\end{array}$ & $\begin{array}{l}\text { R for } \\
\text { ith female }\end{array}$ \\
\hline STATES & elderly $60+$ & $\begin{array}{c}\text { No elderly } \\
60+\end{array}$ & elderly $65+$ & $\begin{array}{c}\text { No elderly } \\
65+\end{array}$ & elderly $75+$ & $\begin{array}{l}\text { No elderly } \\
75+\end{array}$ & Elderly & $\begin{array}{l}\text { Non- } \\
\text { elderly }\end{array}$ & Elderly 60+ & elderly $75+$ \\
\hline $\mathrm{AP}$ & 0.18 & 0.20 & 0.20 & 0.20 & .15 & .16 & 0.17 & 0.20 & 0.18 & 0.14 \\
\hline Assam & 0.45 & 0.49 & 0.46 & 0.48 & .36 & .43 & 0.40 & 0.48 & 0.46 & 0.50 \\
\hline Bihar & 0.52 & 0.58 & 0.5 & 0.58 & .42 & .52 & 0.45 & 0.57 & 0.51 & 0.46 \\
\hline Gujarat & 0.20 & 0.21 & 0.19 & 0.21 & .13 & .18 & $\begin{array}{c}0.16 \\
(0.31)\end{array}$ & $\begin{array}{c}0.21 \\
(0.43)\end{array}$ & 0.19 & 0.1 \\
\hline Haryana & 0.15 & 0.19 & 0.16 & 0.19 & .16 & .15 & 0.13 & 0.18 & 0.18 & 0.23 \\
\hline Karanataka & 0.32 & 0.31 & 0.32 & 0.32 & 0.24 & 0.25 & $\begin{array}{c}0.23 \\
(0.49)\end{array}$ & $\begin{array}{c}0.32 \\
(0.54)\end{array}$ & 0.34 & 0.27 \\
\hline Kerala & 0.18 & 0.14 & 0.17 & 0.15 & 0.14 & 0.12 & $\begin{array}{c}0.15 \\
(0.26)\end{array}$ & $\begin{array}{c}0.15 \\
(0.31)\end{array}$ & 0.17 & 0.17 \\
\hline MP & 0.33 & 0.37 & 0.32 & 0.37 & 0.30 & 0.31 & $\begin{array}{c}0.28 \\
(0.55)\end{array}$ & $\begin{array}{c}0.36 \\
(0.62)\end{array}$ & 0.32 & 0.30 \\
\hline Maharashtra & 0.28 & 0.28 & 0.27 & 0.29 & 0.18 & 0.23 & $\begin{array}{c}0.21 \\
(0.49)\end{array}$ & $\begin{array}{c}0.29 \\
(0.54)\end{array}$ & 0.27 & 0.25 \\
\hline Orissa & 0.41 & 0.51 & 0.41 & 0.5 & 0.34 & 0.44 & 0.39 & 0.49 & 0.45 & 0.38 \\
\hline Punjab & 0.06 & 0.11 & 0.06 & 0.11 & 0.05 & 0.09 & 0.05 & 0.10 & 0.06 & 0.02 \\
\hline Rajasthan & 0.20 & 0.20 & 0.20 & 0.2 & 0.17 & 0.16 & 0.17 & 0.20 & 0.22 & 0.25 \\
\hline Tamilnadu & 0.29 & 0.29 & 0.30 & 0.29 & 0.24 & 0.24 & $\begin{array}{c}0.23 \\
(0.50)\end{array}$ & $\begin{array}{c}0.30 \\
(0.55)\end{array}$ & 0.28 & 0.32 \\
\hline UP & 0.42 & 0.45 & 0.42 & 0.44 & 0.37 & 0.38 & 0.37 & 0.44 & 0.44 & 0.45 \\
\hline WB & 0.41 & 0.52 & 0.39 & 0.51 & 0.34 & 0.45 & 0.37 & 0.50 & 0.43 & 0.47 \\
\hline
\end{tabular}

Notes: These figures show the proportion of total people in each category who live below the state-specific poverty lines. [1] These estimates are the same whether we consider household-level or individual level approach. Numbers in parentheses (column 2) indicate the corresponding Deaton \& Paxson (1995) estimates for 1987-88 for these states. 
TABLE 3. Comparison of poverty likelihood

\begin{tabular}{|c|c|c|c|c|c|c|c|c|c|}
\hline & \multicolumn{3}{|c|}{ Households with } & \multicolumn{3}{|c|}{ Households with } & \multicolumn{3}{|c|}{ Households with } \\
\hline STATES & $\begin{array}{l}\text { elderly } \\
60+\end{array}$ & $\begin{array}{c}\text { no elderly } \\
60+\end{array}$ & $\begin{array}{c}\text { Difference } \\
\text { significant } \\
\text { T-stat }\end{array}$ & elderly $65+$ & $\begin{array}{c}\text { no elderly } \\
65+\end{array}$ & $\begin{array}{c}\text { Difference } \\
\text { significant } \\
\text { T-stat }\end{array}$ & elderly $75+$ & $\begin{array}{c}\text { no elderly } \\
75+\end{array}$ & $\begin{array}{c}\text { Difference } \\
\text { significant } \\
\text { T-stat }\end{array}$ \\
\hline AP & 0.158 & 0.16 & -0.433 & 0.18 & 0.16 & 1.147 & 0.147 & 0.163 & -0.488 \\
\hline Assam & 0.41 & 0.44 & -1.552 & 0.43 & 0.43 & -0.063 & 0.36 & 0.43 & -1.441 \\
\hline Bihar & 0.47 & 0.53 & $-4.377 * *$ & 0.45 & 0.53 & $-4.659 * *$ & 0.42 & 0.52 & $-3.161 * *$ \\
\hline Gujarat & 0.16 & 0.18 & -1.171 & 0.15 & 0.18 & -1.288 & 0.13 & 0.18 & -1.610 \\
\hline Haryana & 0.14 & 0.16 & -0.942 & 0.148 & 0.155 & -0.264 & 0.158 & 0.154 & 0.096 \\
\hline Karanataka & 0.25 & 0.25 & -0.089 & 0.249 & 0.252 & -0.155 & 0.24 & 0.25 & -0.213 \\
\hline Kerala & 0.15 & 0.11 & $3.460 * *$ & 0.15 & 0.11 & $2.467 * *$ & 0.14 & 0.12 & 0.953 \\
\hline MP & 0.28 & 0.32 & $-3.076 * *$ & 0.27 & 0.32 & $-2.938 * *$ & 0.297 & 0.31 & -0.549 \\
\hline Maharashtra & 0.22 & 0.23 & -0.708 & 0.215 & 0.31 & -1.045 & 0.18 & 0.23 & $-1.826 *$ \\
\hline Orissa & 0.38 & 0.45 & $-3.401 * *$ & 0.38 & 0.45 & $-3.002 * *$ & 0.34 & 0.44 & $-2.716 * *$ \\
\hline Punjab & 0.06 & 0.09 & $-3.018 * *$ & 0.06 & 0.09 & $-2.577 * *$ & 0.05 & 0.087 & $-1.832^{*}$ \\
\hline Rajasthan & 0.16 & 0.16 & 0.169 & 0.159 & 0.161 & -0.071 & 0.168 & 0.16 & 0.241 \\
\hline Tamilnadu & 0.24 & 0.24 & -0.063 & 0.239 & 0.237 & 0.123 & 0.238 & 0.237 & 0.20 \\
\hline UP & 0.36 & 0.39 & $2.222 *$ & 0.37 & 0.38 & -1.028 & 0.37 & 0.38 & -0.387 \\
\hline WB & 0.38 & 0.47 & $-4.901 * *$ & 0.36 & 0.46 & $-4.743 * *$ & 0.335 & 0.454 & $-3.204 * *$ \\
\hline
\end{tabular}


TABLE 3. Comparison of poverty likelihood (continued)

\begin{tabular}{|c|c|c|c|c|c|c|c|c|c|}
\hline & \multicolumn{3}{|c|}{ Households with } & \multicolumn{3}{|c|}{ Households with } & \multicolumn{3}{|c|}{ Households with } \\
\hline STATES & $\begin{array}{c}\text { Female } \\
\text { elderly } \\
60+\end{array}$ & $\begin{array}{c}\text { no female } \\
\text { elderly } \\
60+\end{array}$ & $\begin{array}{c}\text { Difference } \\
\text { significant } \\
\text { T-stat }\end{array}$ & $\begin{array}{c}\text { Female } \\
\text { elderly } 65+\end{array}$ & $\begin{array}{c}\text { no female } \\
\text { elderly } \\
65+\end{array}$ & $\begin{array}{c}\text { Difference } \\
\text { significant } \\
\text { T-stat }\end{array}$ & $\begin{array}{c}\text { Female } \\
\text { elderly } 75+\end{array}$ & $\begin{array}{c}\text { no female } \\
\text { elderly } \\
75+\end{array}$ & $\begin{array}{c}\text { Difference } \\
\text { significant } \\
\text { T-stat }\end{array}$ \\
\hline AP & 0.159 & 0.163 & -0.199 & 0.18 & 0.16 & 0.839 & 0.12 & 0.16 & -1.202 \\
\hline Assam & 0.426 & 0.432 & -0.232 & 0.50 & 0.43 & $1.862 *$ & 0.47 & 0.43 & 0.479 \\
\hline Bihar & 0.46 & 0.53 & $-3.603 * *$ & 0.46 & 0.53 & $-2.865^{*}$ & 0.498 & 0.499 & $-1.821 *$ \\
\hline Gujarat & 0.16 & 0.18 & -1.030 & 0.14 & 0.18 & $1.791 *$ & 0.09 & 0.18 & $-2.495^{*}$ \\
\hline Haryana & 0.17 & 0.15 & 0.500 & 0.159 & 0.153 & 0.202 & 0.23 & 0.15 & 1.125 \\
\hline Karanataka & 0.27 & 0.25 & 0.915 & 0.26 & 0.25 & 0.462 & 0.21 & 0.25 & -0.739 \\
\hline Kerala & 0.16 & 0.11 & $2.885 * *$ & 0.16 & 0.12 & $2.147 *$ & 0.17 & 0.12 & 1.474 \\
\hline MP & 0.27 & 0.32 & $-2.724 * *$ & 0.28 & 0.32 & $-1.923^{*}$ & 0.27 & 0.31 & -1.207 \\
\hline Maharashtra & 0.216 & 0.23 & -0.866 & 0.21 & 0.23 & -0.983 & 0.21 & 0.23 & -0.498 \\
\hline Orissa & 0.42 & 0.44 & -0.669 & 0.41 & 0.44 & -0.994 & 0.39 & 0.44 & -0.886 \\
\hline Punjab & 0.06 & 0.09 & $-2.388 *$ & 0.07 & 0.08 & -1.140 & 0.15 & 0.28 & $-3.864 * *$ \\
\hline Rajasthan & 0.18 & 0.16 & 1.097 & 0.163 & 0.16 & 0.178 & 0.20 & 0.16 & 1.040 \\
\hline Tamilnadu & 0.23 & 0.24 & -0.440 & 0.24 & 0.237 & 0.160 & 0.25 & 0.24 & 0.238 \\
\hline UP & 0.38 & 0.379 & 0.116 & 0.39 & 0.38 & 0.484 & 0.40 & 0.38 & 0.748 \\
\hline WB & 0.41 & 0.45 & $-2.046^{*}$ & 0.40 & 0.45 & $-1.903 *$ & 0.41 & 0.45 & -0.688 \\
\hline
\end{tabular}

Note. A household is considered to be poor if its average per capita monthly expenditure (APCE) is less than the state poverty line in 1995.

Poverty likelihood is then calculated as the simple proportion of total households living with/without elderly of different categories $60+, 65+$ and $75+$. We also compute the corresponding t-statistics for comparison of the proportions of households with and without elderly. 
Table 4. A Comparison of demographic composition of households with and without elderly members

\begin{tabular}{|c|c|c|c|c|c|c|c|c|c|c|}
\hline & $\begin{array}{l}\text { Household } \\
\text { size }\end{array}$ & & $\begin{array}{l}\text { Dependency } \\
\text { ratio }\end{array}$ & & $\begin{array}{l}\text { Household } \\
\text { size }\end{array}$ & & $\begin{array}{l}\text { Dependency } \\
\text { ratio }\end{array}$ & & $\begin{array}{l}\text { Curren } \\
\text { partici } \\
\text { among }\end{array}$ & $\begin{array}{l}\text { nomic } \\
\text { n rate }\end{array}$ \\
\hline States & $\begin{array}{l}\text { With old } \\
60+\end{array}$ & $\begin{array}{l}\text { Without } \\
\text { old } 60+\end{array}$ & $\begin{array}{l}\text { With old } \\
60+\end{array}$ & $\begin{array}{l}\text { Without } \\
\text { old } 60+\end{array}$ & $\begin{array}{l}\text { With old } \\
75+\end{array}$ & $\begin{array}{l}\text { Without } \\
\text { old } 75+\end{array}$ & $\begin{array}{l}\text { With old } \\
75+\end{array}$ & $\begin{array}{l}\text { Without } \\
\text { old } 75+\end{array}$ & $\begin{array}{l}\text { elderly } \\
60+\end{array}$ & $\begin{array}{c}\text { elderly } \\
75+\end{array}$ \\
\hline AP & 5.14 & 4.45 & 0.25 & 0.35 & 5.53 & 4.56 & 0.47 & 0.32 & 0.39 & 0.17 \\
\hline t-statistic & $6.933 * *$ & & $12.616^{* *}$ & & $3.568 * *$ & & $8.329 * *$ & & & \\
\hline Assam & 6.75 & 4.95 & 0.29 & 0.38 & 4.15 & 2.24 & 0.45 & 0.36 & 0.32 & 0.09 \\
\hline t-statistic & $14.300 * *$ & & $10.664 * *$ & & $4.170 * *$ & & $4.021 * *$ & & & \\
\hline Bihar & 7.16 & 5.46 & 0.37 & 0.41 & 7.88 & 5.74 & 0.55 & 0.39 & 0.43 & 0.26 \\
\hline t-statistic & $15.566^{* *}$ & & $6.329 * *$ & & $7.767 * *$ & & $14.02 * *$ & & & \\
\hline Gujarat & 6.14 & 5.31 & 0.29 & 0.35 & 6.33 & 5.46 & 0.48 & 0.33 & 0.34 & 0.28 \\
\hline t-statistic & $5.913 * *$ & & $5.018 * *$ & & $2.689 * *$ & & $7.839 * *$ & & & \\
\hline Haryana & 6.75 & 5.57 & 0.35 & 0.40 & 7.03 & 5.80 & 0.51 & 0.37 & 0.24 & 0.06 \\
\hline t-statistic & $6.017 * *$ & & $3.639 * *$ & & $3.482 * *$ & & $5.990 * *$ & & & \\
\hline Karanataka & 6.94 & 5.19 & 0.31 & 0.36 & 7.48 & 5.53 & 0.47 & 0.34 & 0.38 & 0.17 \\
\hline t-statistic & $10.309 * *$ & & $4.773 * *$ & & $3.835 * *$ & & $7.205 * *$ & & & \\
\hline Kerala & 5.73 & 4.43 & 0.28 & 0.29 & 5.68 & 4.83 & 0.45 & 0.27 & 0.30 & 0.12 \\
\hline t-statistic & $14.143^{* *}$ & & 1.364 & & $5.315 * *$ & & $14.789 * *$ & & & \\
\hline $\mathrm{MP}$ & 6.84 & 5.25 & 0.33 & 0.39 & 7.35 & 5.51 & 0.49 & 0.37 & 0.40 & 0.17 \\
\hline t-statistic & $13.360 * *$ & & $8.909 * *$ & & $7.089 * *$ & & $9.473 * *$ & & & \\
\hline Maharashtra & 6.01 & 4.92 & 0.31 & 0.37 & 6.36 & 5.17 & 0.47 & 0.34 & 0.44 & 0.16 \\
\hline t-statistic & $11.034 * *$ & & $8.228 * *$ & & $5.645 * *$ & & $8.892 * *$ & & & \\
\hline Orissa & 6.19 & 4.67 & 0.30 & 0.35 & 6.61 & 4.98 & 0.49 & 0.33 & 0.38 & 0.09 \\
\hline t-statistic & $11.894 * *$ & & $5.992 * *$ & & $6.050 * *$ & & $11.081 * *$ & & & \\
\hline Punjab & 6.73 & 5.29 & 0.33 & 0.36 & 6.76 & 5.56 & 0.48 & 0.34 & 0.24 & 0.07 \\
\hline t-statistic & $10.131 * *$ & & $2.293 *$ & & $4.888 * *$ & & $8.568 * *$ & & & \\
\hline Rajasthan & 6.72 & 5.39 & 0.36 & 0.41 & 7.28 & 5.58 & 0.55 & 0.39 & 0.38 & 0.15 \\
\hline t-statistic & $9.022 * *$ & & $4.868 * *$ & & $5.368 * *$ & & $10.035^{* *}$ & & & \\
\hline Tamil Nadu & 4.47 & 4.15 & 0.23 & 0.30 & 4.57 & 4.20 & 0.48 & 0.28 & 0.47 & 0.23 \\
\hline
\end{tabular}




\begin{tabular}{|c|c|c|c|c|c|c|c|c|c|c|}
\hline t-statistic & $3.601 * *$ & & $7.609 * *$ & & $1.863 *$ & & $11.859 * *$ & & & \\
\hline UP & 7.08 & 5.64 & 0.35 & 0.42 & 7.78 & 5.93 & 0.53 & 0.39 & 0.42 & 0.23 \\
\hline t-statistic & $15.694 * *$ & & $11.419 * *$ & & $9.223 * *$ & & $16.541 * *$ & & & \\
\hline WB & 6.39 & 4.94 & 0.29 & 0.39 & 6.38 & 5.18 & 0.46 & 0.36 & 0.35 & 0.15 \\
\hline t-statistic & $12.720 * *$ & & $12.074 * *$ & & $4.618 * *$ & & $7.660 * *$ & & & \\
\hline All India & 6.38 & 5.03 & 0.31 & 0.37 & 6.75 & 5.27 & 0.49 & 0.35 & 0.39 & 0.17 \\
\hline t-statistic & $46.631 * *$ & & $30.388 * *$ & & $22.667 * *$ & & $40.833 * *$ & & & \\
\hline
\end{tabular}

Note: T-statistics are computed to compare the means of variables between households with and without elderly members. Here $*$ denotes significance at least at $5 \%$ and $* *$ denote that at $1 \%$ or lower level.

Table 5. Relationship between income/expenditure and elderly poverty and mortality rates

\begin{tabular}{|c|c|c|c|}
\hline & $\begin{array}{l}\text { (1) NSS 60 } \\
\text { Household-level }\end{array}$ & $\begin{array}{l}\text { (2) IIEF database } \\
\text { Individual level }\end{array}$ & $\begin{array}{l}\text { (3) NSS 52nd round } \\
\text { District-level }\end{array}$ \\
\hline Explanatory variables & $\begin{array}{l}\text { Dep: Death of } 55+\text { in } \\
\text { households with } 55+\end{array}$ & Dep: Death of father & $\begin{array}{l}\text { Dep: HCR of hhs. With } \\
\text { elderly } 60+\text { relative to } \\
\text { HCR of hhs. without } 60+\end{array}$ \\
\hline $\log ($ APCE) & $-0.19(4.960) * *$ & & $0.13(2.318)^{*}$ \\
\hline Log(income) & & $0.04(14.44) * *[1]$ & \\
\hline Age $55+$ & $0.03(12.121)^{* *}$ & & - \\
\hline Male 55+ & $1.01(3.292)^{* *}$ & & - \\
\hline State-effects & Yes & & Yes \\
\hline Intercept & Yes & & Yes \\
\hline Log-L & -1388.570 & -23978.642 & \\
\hline Chi-square & 126.9693 & 6164.31 & \\
\hline F-stat & & & $4.184 * *$ \\
\hline Nobs & 18829 & 40838 & 462 \\
\hline
\end{tabular}

Note: T-statistics are shown in the parentheses. '*' denotes significance at $10 \%$ level and '**' at $1 \%$ level.

[1] Other control variables include age and square of age of the individual.

[2] IIEF - Invest India Economic Foundation, www.iief.com 
Figure 1: Relative elderly poverty rates across states, NSS 52

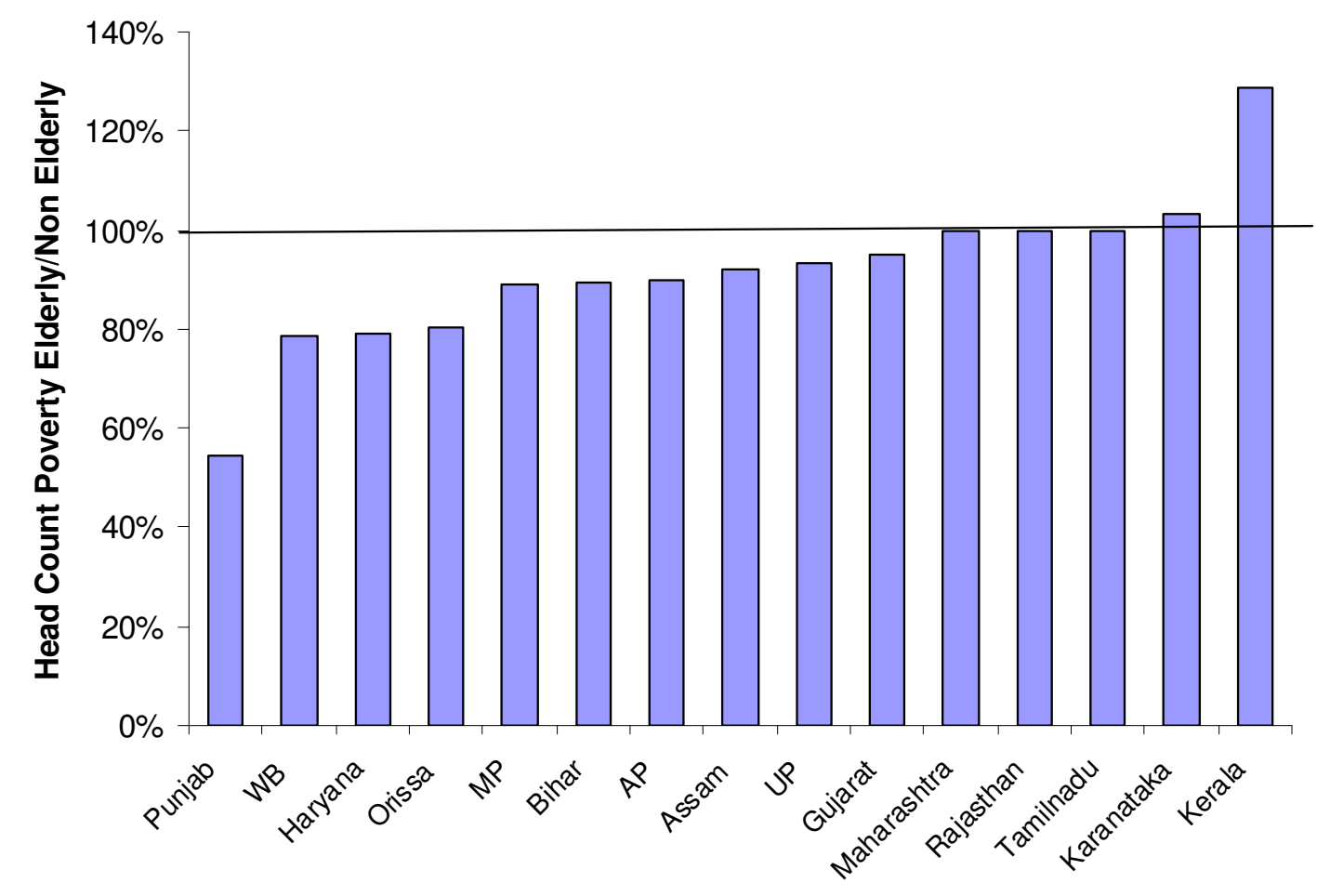

Source: Table 2. 
Figure 2: Expenditure distribution of predicted probability of death at age 55+

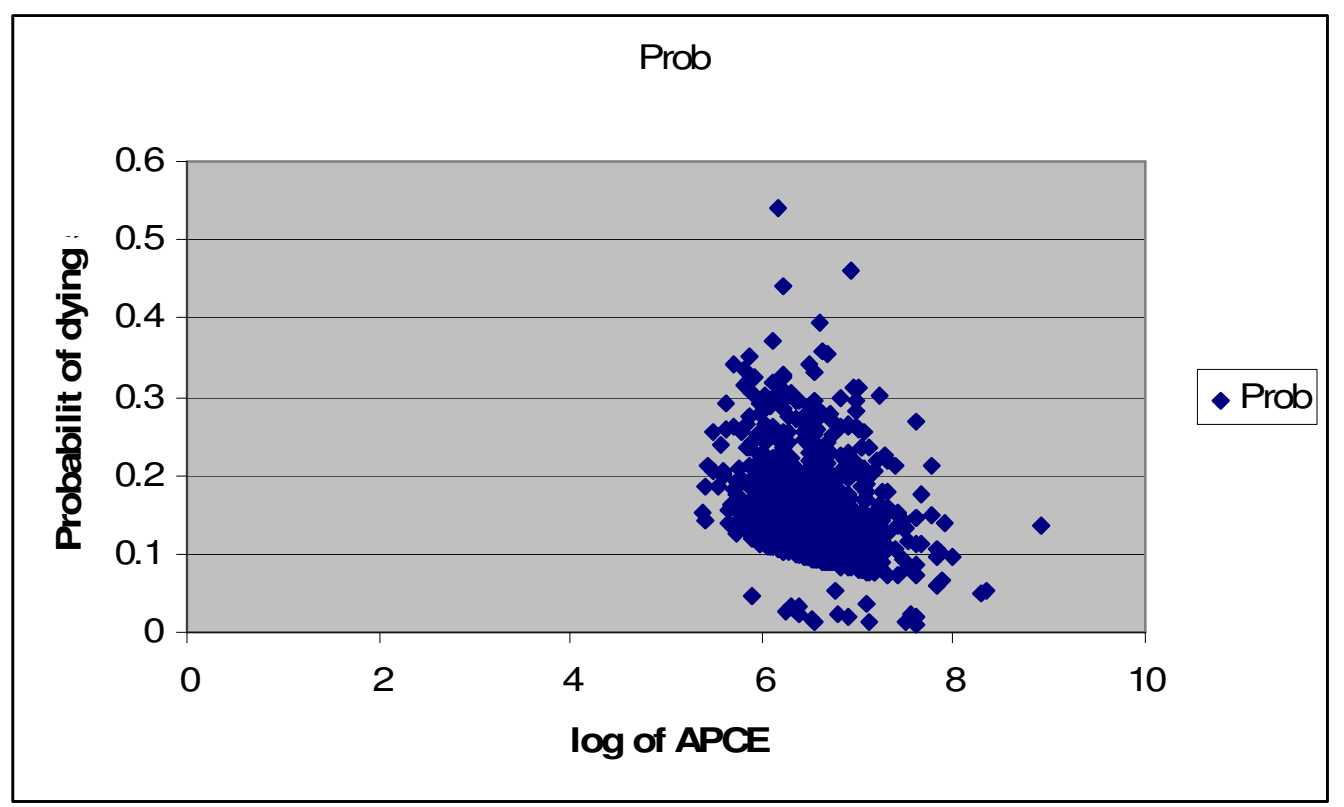


Figure 3. Age distribution of predicted elderly male/female 55+ mortality rates (\%)

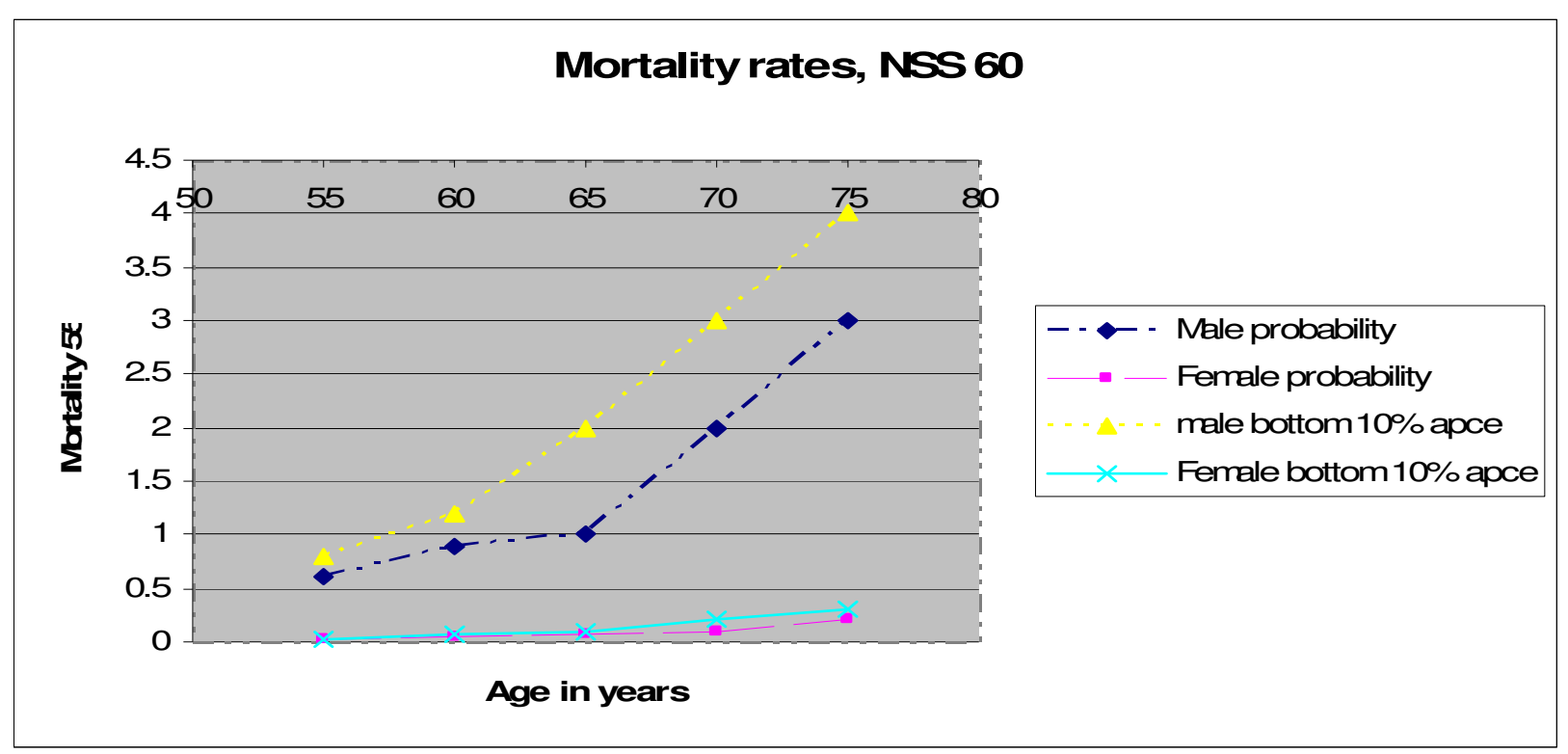




\section{Appendix}

Table A1. Comparison of Mean APCE between households with and without elderly members

\begin{tabular}{|l|l|l|l|l|}
\hline & With old 60+ & $\begin{array}{l}\text { Without old } \\
\mathbf{6 0 +}\end{array}$ & With old 75 & $\begin{array}{l}\text { Without old } \\
\mathbf{7 5 +}\end{array}$ \\
\hline AP & 323.8 & 308.5 & 323.8 & 311.0 \\
\hline T-stat [1] & $2.352^{* *}$ & & 0.958 & \\
\hline Assam & 313.3 & 312.4 & 345.3 & 311.7 \\
\hline T-stat & 0.189 & & $2.177^{*}$ & \\
\hline Bihar & 282.4 & 275.7 & 297.7 & 276.3 \\
\hline T-stat & $1.855^{*}$ & & $2.599 * *$ & \\
\hline Gujarat & 228.0 & 193.7 & 406.6 & 394.6 \\
\hline T-stat & $2.130^{*}$ & & 0.772 & \\
\hline Haryana & 461.9 & 479.7 & 435.1 & 477.9 \\
\hline T-stat & -0.764 & & $-1.758^{*}$ & \\
\hline Karnataka & 331.4 & 330.9 & 370.8 & 329.4 \\
\hline T-stat & 0.054 & & $2.144 *$ & \\
\hline Kerala & 455.7 & 503.2 & 460.5 & 488.4 \\
\hline T-stat & $-3.342^{* *}$ & & -1.557 & \\
\hline MP & 314.8 & 305.0 & 321.2 & 306.4 \\
\hline T-stat & $1.938^{*}$ & & 0.932 & \\
\hline Maharashtra & 345.1 & 342.5 & 363.7 & 342.1 \\
\hline T-stat & 0.439 & & 1.606 & \\
\hline Orissa & 279.1 & 272.2 & 293.3 & 272.9 \\
\hline T-stat & 1.315 & & $2.278^{*}$ & \\
\hline Punjab & 549.0 & 512.3 & 548.9 & 519.3 \\
\hline T-stat & $2.774^{*}$ & & 1.382 & \\
\hline Rajasthan & 378.4 & 389.9 & 378.3 & 388.1 \\
\hline T-stat & $-1.743^{*}$ & & -0.809 & \\
\hline Tamil Nadu & 341.5 & 336.4 & 339.2 & 337.3 \\
\hline T-stat & 0.818 & & 0.142 & \\
\hline & & & & \\
\hline
\end{tabular}




\begin{tabular}{|l|l|l|l|l|}
\hline UP & 330.3 & 325.6 & 320.8 & 327.3 \\
\hline T-stat & 1.132 & & -1.017 & \\
\hline West Bengal & 334.5 & 301.9 & 145.0 & 136.3 \\
\hline T-stat & $5.820^{* *}$ & & $3.891^{* *}$ & \\
\hline All India & 357.4 & 350.7 & 369.8 & 351.4 \\
\hline T-stat & $3.735^{* *}$ & & $5.310^{* *}$ & \\
\hline
\end{tabular}

Note: The table above reports the independent sample t-statistics used for comparison of mean APCE between households with and without elderly $(60+$ or $75+)$. Please note that the reported t-statistics here assume unequal variances for the two sub-samples. Here $*$ denotes significance at least at $5 \%$ and $* *$ denote that at $1 \%$ or lower level.

TABLE A2. Other unadjusted household-level rural poverty indices

\begin{tabular}{|l|r|r|r|r|}
\hline & \multicolumn{2}{|c|}{ Population living with elderly 60+ } & \multicolumn{2}{c|}{ Population living without elderly 60+ } \\
\hline \multicolumn{1}{|c|}{ STATE } & $\begin{array}{c}\text { Poverty gap } \\
\text { index }\end{array}$ & $\begin{array}{c}\text { Squared poverty } \\
\text { gap index }\end{array}$ & $\begin{array}{c}\text { Poverty gap } \\
\text { index }\end{array}$ & $\begin{array}{c}\text { Squared poverty } \\
\text { gap index }\end{array}$ \\
\hline AP & .0051 & .0013 & .0059 & .0015 \\
\hline Assam & .0118 & .0036 & .0187 & .0057 \\
\hline Bihar & .0140 & .0043 & .0222 & .0070 \\
\hline Gujarat & .0043 & .0011 & .0060 & .0017 \\
\hline Haryana & .0032 & .0008 & .0044 & .0010 \\
\hline Karanataka & .0076 & .0023 & .0105 & .0033 \\
\hline Kerala & .0042 & .0010 & .0038 & .0010 \\
\hline MP & .0069 & .0019 & .0119 & .0033 \\
\hline Maharashtra & .0062 & .0016 & .0097 & .0031 \\
\hline Orissa & .0118 & .0035 & .0219 & .0006 \\
\hline Punjab & .0012 & .0003 & .0024 & .0011 \\
\hline Rajasthan & .0033 & .0008 & .0044 & .0028 \\
\hline Tamilnadu & .0098 & .0028 & .0101 & .0043 \\
\hline UP & .0108 & .0033 & .0142 & .0059 \\
\hline WB & .0109 & .0030 & .0201 & \\
\hline
\end{tabular}




\section{TABLE A3. Equivalence scale adjusted poverty head count ratio}

\begin{tabular}{|c|c|c|c|c|c|c|c|c|c|c|c|c|}
\hline & \multicolumn{3}{|c|}{$\begin{array}{c}\text { Households with elderly } 60+ \\
\text { Weights }\end{array}$} & \multicolumn{3}{|c|}{$\begin{array}{c}\text { Households without elderly60+ } \\
\text { Weights }\end{array}$} & \multicolumn{3}{|c|}{$\begin{array}{c}\text { Households with elderly } 75+ \\
\text { Weights }\end{array}$} & \multicolumn{3}{|c|}{$\begin{array}{c}\text { Households without elderly75+ } \\
\text { Weights }\end{array}$} \\
\hline STATES & $1,1,0.6$ & $1,0.8,0.6$ & $1,0.7,0.5$ & $1,1,0.6$ & $1,0.8,0.6$ & $1,0.7,0.5$ & $1,1,0.6$ & $1,0.8,0.6$ & $1,0.7,0.5$ & $1,1,0.6$ & $1,0.8,0.6$ & $1,0.7,0.5$ \\
\hline AP & .03 & .03 & .22 & .18 & .15 & .21 & .18 & .14 & .02 & .15 & .12 & .09 \\
\hline Assam & .06 & .05 & .24 & .19 & .14 & .35 & .30 & .25 & .04 & .31 & .26 & .21 \\
\hline Bihar & .06 & .06 & .25 & .22 & .20 & .40 & .37 & .31 & .04 & .32 & .29 & .24 \\
\hline Gujarat & .03 & .02 & .20 & .18 & .15 & .21 & .19 & .16 & .02 & .16 & .14 & .12 \\
\hline Haryana & .04 & .04 & .20 & .18 & .17 & .18 & .15 & .12 & .03 & .15 & .12 & .09 \\
\hline Karanatak & .06 & .04 & .15 & .12 & .09 & .26 & .23 & .19 & .03 & .22 & .19 & .15 \\
\hline Kerala & .08 & .06 & .15 & .13 & .11 & .18 & .14 & .11 & .04 & .15 & .11 & .08 \\
\hline MP & .04 & .03 & .16 & .13 & .10 & .30 & .27 & .23 & .03 & .24 & .21 & .18 \\
\hline Marras & .06 & .05 & .17 & .15 & .13 & .26 & .23 & .19 & .04 & .21 & .18 & .14 \\
\hline Orissa & .08 & .06 & .23 & .19 & .13 & .40 & .35 & .30 & .05 & .34 & .30 & .24 \\
\hline Punjab & .02 & .02 & .10 & .09 & .08 & .15 & .13 & .10 & .01 & .12 & .10 & .08 \\
\hline Rajasthan & .03 & .02 & .14 & .13 & .12 & .21 & .19 & .15 & .02 & .16 & .13 & .10 \\
\hline Tamilnadu & .04 & .03 & .29 & .26 & .20 & .27 & .23 & .19 & .03 & .20 & .17 & .13 \\
\hline UP & .08 & .07 & .26 & .22 & .19 & .34 & .30 & .26 & .06 & .27 & .24 & .19 \\
\hline WB & .05 & .04 & .21 & .18 & .15 & .36 & .32 & .27 & .03 & .31 & .27 & .22 \\
\hline
\end{tabular}

Note: These estimates are not available for J\&K as we were unable to find a poverty line for the state in 1995-96. It is clear that the poverty head count ratio declines as we adjust for the equivalence scale and also that these adjusted poverty rates are less for households with elderly in all the Indian states. 
TABLE A3. Equivalence scale adjusted poverty head count ratio (continued)

\begin{tabular}{lcccccc} 
& \multicolumn{3}{c}{$\begin{array}{c}\text { Equivalence scale adjusted } \\
\text { for female elderly } 60+\end{array}$} & \multicolumn{3}{c}{$\begin{array}{c}\text { Equivalence scale adjusted } \\
\text { for female elderly } 75+\end{array}$} \\
AP & $1,1,0.6$ & $1,0.8,0.6$ & $1,0.7,0.5$ & $1,1,0.6$ & $1,0.8,0.6$ & $1,0.7,0.5$ \\
Assam & 0.11 & 0.1 & 0.07 & 0.10 & 0.09 & 0.05 \\
Bihar & 0.17 & 0.14 & 0.10 & 0.17 & 0.16 & 0.07 \\
Gujarat & 0.18 & 0.16 & 0.13 & 0.15 & 0.11 & 0.09 \\
Haryana & 0.08 & 0.06 & 0.05 & 0.10 & 0.10 & 0.08 \\
Karanatak & 0.11 & 0.1 & 0.08 & 0.17 & 0.14 & 0.14 \\
Kerala & 0.14 & 0.11 & 0.07 & 0.06 & 0.05 & 0.02 \\
MP & 0.11 & 0.09 & 0.07 & 0.13 & 0.11 & 0.08 \\
Marras & 0.1 & 0.09 & 0.08 & 0.09 & 0.07 & 0.05 \\
Orissa & 0.11 & 0.1 & 0.08 & 0.05 & 0.04 & 0.04 \\
Punjab & 0.17 & 0.14 & 0.10 & 0.13 & 0.09 & 0.03 \\
Rajasthan & 0.05 & 0.04 & 0.03 & 0.05 & 0.04 & 0.03 \\
Tamilnadu & 0.07 & 0.06 & 0.05 & 0.07 & 0.06 & 0.05 \\
UP & 0.16 & 0.13 & 0.12 & 0.18 & 0.14 & 0.12 \\
WB & 0.15 & 0.14 & 0.11 & 0.16 & 0.14 & 0.09 \\
& 0.17 & 0.14 & 0.12 & 0.13 & 0.10 & 0.10
\end{tabular}


Table A4: Size economies of scale adjusted poverty head count ratio

\begin{tabular}{|c|c|c|c|c|c|c|c|c|c|c|c|c|c|c|c|c|}
\hline & \multicolumn{4}{|c|}{$\begin{array}{l}\text { With old } 60+ \\
\text { Weights }\end{array}$} & \multicolumn{4}{|c|}{$\begin{array}{l}\text { Without old } 60+ \\
\text { Weights }\end{array}$} & \multicolumn{4}{|c|}{$\begin{array}{l}\text { With old 75+ } \\
\text { Weights }\end{array}$} & \multicolumn{4}{|c|}{$\begin{array}{l}\text { Without old 75+ } \\
\text { Weights }\end{array}$} \\
\hline States & 0.8 & 0.6 & 0.4 & 0.2 & 0.8 & 0.6 & 0.4 & 0.2 & 0.8 & 0.6 & 0.4 & 0.2 & 0.8 & 0.6 & 0.4 & 0.2 \\
\hline $\mathrm{AP}$ & 0.04 & 0.04 & 0.04 & 0.05 & 0.23 & 0.26 & 0.29 & 0.21 & .15 & .13 & .14 & .16 & .2 & .21 & .24 & .27 \\
\hline Assam & 0.12 & 0.1 & 0.08 & 0.07 & 0.48 & 0.47 & 0.46 & 0.49 & .34 & .26 & .19 & .16 & .5 & .44 & .42 & .41 \\
\hline Bihar & 0.16 & 0.13 & 0.11 & 0.1 & 0.55 & 0.54 & 0.53 & 0.57 & .35 & .29 & .26 & .23 & .5 & .51 & .49 & .48 \\
\hline Gujarat & 0.05 & 0.04 & 0.04 & 0.04 & 0.18 & 0.19 & 0.2 & 0.19 & .11 & .09 & .09 & .09 & .2 & .18 & .17 & .18 \\
\hline Haryana & 0.06 & 0.05 & 0.05 & 0.05 & 0.19 & 0.19 & 0.2 & 0.19 & .14 & .13 & .12 & .10 & .2 & .17 & .17 & .18 \\
\hline Karanata & 0.1 & 0.08 & 0.07 & 0.06 & 0.3 & 0.29 & 0.3 & 0.3 & .18 & .15 & .12 & .12 & .3 & .27 & .26 & .26 \\
\hline Kerala & 0.1 & 0.07 & 0.06 & 0.06 & 0.11 & 0.12 & 0.14 & 0.12 & .11 & .08 & .09 & .09 & .1 & .11 & .10 & .12 \\
\hline MP & 0.08 & 0.07 & 0.06 & 0.05 & 0.36 & 0.36 & 0.36 & 0.36 & .22 & .18 & .15 & .13 & .3 & .32 & .32 & .32 \\
\hline Marras & 0.1 & 0.08 & 0.07 & 0.07 & 0.26 & 0.26 & 0.27 & 0.26 & .13 & .09 & .10 & .09 & .2 & .24 & .23 & .23 \\
\hline Orissa & 0.14 & 0.12 & 0.11 & 0.11 & 0.5 & 0.5 & 0.5 & 0.51 & .21 & .17 & .16 & .15 & .5 & .44 & .44 & .43 \\
\hline Punjab & 0.02 & 0.02 & 0.02 & 0.02 & 0.11 & 0.12 & 0.14 & 0.1 & .05 & .04 & .06 & .05 & .1 & .10 & .10 & .11 \\
\hline Rajasthn & 0.04 & 0.03 & 0.03 & 0.03 & 0.17 & 0.18 & 0.2 & 0.17 & .15 & .10 & .07 & .08 & .2 & .15 & .17 & .18 \\
\hline T Nadu & 0.07 & 0.05 & 0.05 & 0.05 & 0.23 & 0.22 & 0.22 & 0.26 & .22 & .17 & .18 & .18 & .3 & .23 & .22 & .22 \\
\hline UP & 0.17 & 0.14 & 0.12 & 0.12 & 0.41 & 0.41 & 0.41 & 0.42 & .34 & .27 & .20 & .18 & .4 & .38 & .37 & .36 \\
\hline WB & 0.11 & 0.09 & 0.08 & 0.07 & 0.5 & 0.48 & 0.47 & 0.51 & .26 & .20 & .19 & .16 & .5 & .45 & .44 & .42 \\
\hline
\end{tabular}


Table A4: Size economies of scale adjusted poverty head count ratio (continued)

\begin{tabular}{|c|c|c|c|c|c|c|c|c|}
\hline \multirow[b]{2}{*}{ state } & \multicolumn{4}{|c|}{$\begin{array}{l}\text { Size economies adjusted for female } \\
\text { elderly }\end{array}$} & \multicolumn{4}{|c|}{$\begin{array}{l}\text { Size economies adjusted for female } \\
\text { elderly } 75+\text { with weights }\end{array}$} \\
\hline & 0.8 & 0.6 & 0.4 & 0.2 & 0.8 & 0.6 & 0.4 & 0.2 \\
\hline AP & 0.16 & 0.15 & 0.15 & 0.16 & 0.13 & 0.08 & 0.08 & 0.12 \\
\hline Assam & 0.38 & 0.3 & 0.25 & 0.23 & 0.47 & 0.34 & 0.25 & 0.22 \\
\hline Bihar & 0.44 & 0.36 & 0.31 & 0.28 & 0.38 & 0.33 & 0.24 & 0.21 \\
\hline Gujarat & 0.16 & 0.13 & 0.12 & 0.11 & 0.09 & 0.08 & 0.1 & 0.09 \\
\hline Haryana & 0.16 & 0.13 & 0.13 & 0.12 & 0.21 & 0.22 & 0.2 & 0.13 \\
\hline Karanata & 0.26 & 0.21 & 0.19 & 0.17 & 0.14 & 0.13 & 0.12 & 0.13 \\
\hline Kerala & 0.14 & 0.11 & 0.1 & 0.1 & 0.12 & 0.12 & 0.11 & 0.12 \\
\hline MP & 0.24 & 0.21 & 0.17 & 0.16 & 0.21 & 0.18 & 0.17 & 0.16 \\
\hline Marras & 0.18 & 0.15 & 0.14 & 0.13 & 0.15 & 0.09 & 0.09 & 0.07 \\
\hline Orissa & 0.33 & 0.28 & 0.26 & 0.24 & 0.24 & 0.21 & 0.19 & 0.16 \\
\hline Punjab & 0.05 & 0.05 & 0.05 & 0.05 & 0.03 & 0.03 & 0.05 & 0.07 \\
\hline Rajasthn & 0.13 & 0.11 & 0.11 & 0.11 & 0.18 & 0.12 & 0.08 & 0.08 \\
\hline T Nadu & 0.25 & 0.21 & 0.22 & 0.21 & 0.21 & 0.12 & 0.13 & 0.14 \\
\hline UP & 0.35 & 0.29 & 0.24 & 0.23 & 0.39 & 0.31 & 0.22 & 0.2 \\
\hline WB & 0.36 & 0.29 & 0.25 & 0.21 & 0.34 & 0.25 & 0.22 & 0.17 \\
\hline
\end{tabular}


Table A5. Effects of presence of an elderly $60+$ and 75+ on incidence of poverty, NSS 52

\begin{tabular}{|c|c|c|c|c|}
\hline & \multicolumn{2}{|c|}{$\begin{array}{l}\text { Logit estimates } \\
\text { of incidence of poverty }\end{array}$} & \multicolumn{2}{|c|}{$\begin{array}{l}\text { Logit estimates } \\
\text { of incidence of poverty }\end{array}$} \\
\hline & $\begin{array}{l}\text { Coefficient of } \\
\text { Old60+ }\end{array}$ & $\begin{array}{l}\text { LR chi-square } \\
\text { statistic }\end{array}$ & Coeff of OLD75 & Chi-square \\
\hline $\mathrm{AP}[1]$ & -0.09 & $566.6 * *$ & -0.22 & $466.5 * *$ \\
\hline Assam & $-0.50 * *$ & $412.3 * *$ & $-0.61 * *$ & $182.1 * *$ \\
\hline Bihar & $-0.39 * *$ & $970.4 * *$ & $-0.53 * *$ & $758.4 * *$ \\
\hline Gujarat & $-0.25 * *$ & $368.3 * *$ & -0.41 & $334.6 * *$ \\
\hline Haryana & -0.26 & $172.2 * *$ & $-0.09 * *$ & $132.5 * *$ \\
\hline Karnataka & $-0.40 *$ & $356.8 * *$ & -0.39 & $295.3 * *$ \\
\hline Kerala & $0.11 *$ & $167.1 * *$ & -0.02 & $142.7 * *$ \\
\hline MP & $-0.41 * *$ & $924.5 * *$ & -0.18 & $839.5^{* *}$ \\
\hline Maharashtra & $-0.20 * *$ & $670.3 * *$ & $-0.54 * *$ & $576.4 * *$ \\
\hline Orissa & $-0.28 * *$ & $704.3 * *$ & $-0.44 * *$ & $631.9 * *$ \\
\hline Punjab & $-0.54 * *$ & $217.2 * *$ & $-0.72 * *$ & $155.2 * *$ \\
\hline Rajasthan & -0.12 & $348.9 * *$ & -0.26 & $325.9 * *$ \\
\hline Tamilnadu & -0.02 & $526.5 * *$ & -0.04 & $482.1 * *$ \\
\hline $\mathrm{UP}$ & $-0.26 * *$ & 993.2 & $-0.22 * *$ & $817.4^{* *}$ \\
\hline $\mathrm{WB}$ & $-0.45 * *$ & $768.5 * *$ & $-0.55 * *$ & $591.9 * *$ \\
\hline All India [2] & $-0.24 * *$ & $16243.6^{* *}$ & $-0.32 * *$ & $14372.2 * *$ \\
\hline
\end{tabular}

Note: [1] Other control variables include dummy variables for scheduled caste and scheduled tribe. [2] Here, in addition to other control variables as noted in [1], we control for regional dummies as well. Here * denotes significance at least at $10 \%$ and $* *$ denote that at $1 \%$ or lower level. 
Table A6. Average share of elderly in sample households

\begin{tabular}{|c|c|c|c|}
\hline & Proportion of elderly 55+ & Proportion of elderly 60+ & Proportion of elderly 75+ \\
\hline MPCE quintile 1 & 0.2801 & 0.2021 & 0.0276 \\
\hline MPCE quintile 2 & 0.3175 & 0.2317 & 0.0308 \\
\hline MPCE quintile 3 & 0.3329 & 0.2407 & 0.0348 \\
\hline MPCE quintile 4 & 0.3620 & 0.2638 & 0.0494 \\
\hline MPCE quintile 5 & 0.4303 & 0.3226 & 0.0277 \\
\hline Lowest MPCE decile & 0.2736 & 0.1952 & 0.0557 \\
\hline Highest MPCE decile & 0.4692 & 0.3529 & \\
\hline
\end{tabular}


Table A7. Poverty and death rates, NSS 60

\begin{tabular}{|l|l|l|l|l|c|}
\hline & \multicolumn{3}{|l|}{ Household poverty likelihood } & \multicolumn{2}{l|}{ Mean death rates for 55+ } \\
\hline State & $\begin{array}{l}\text { With } \\
60+\end{array}$ & $\begin{array}{l}\text { N0 } \\
60+\end{array}$ & T-stat & Sample & Predicted \\
\hline AP & 0.12 & 0.11 & 1.070 & 0.012 & 0.0147 \\
\hline Assam & 0.24 & 0.23 & 0.780 & 0.015 & 0.0127 \\
\hline Bihar & 0.32 & 0.38 & $-3.984^{* *}$ & 0.013 & 0.0145 \\
\hline Gujarat & 0.14 & 0.18 & $-2.257^{*}$ & 0.008 & 0.0147 \\
\hline Haryana & 0.09 & 0.08 & 0.783 & 0.014 & 0.0149 \\
\hline J\&K & 0.05 & 0.03 & 0.911 & 0.005 & 0.0126 \\
\hline Karnataka & 0.19 & 0.23 & $-2.066^{*}$ & 0.009 & 0.0139 \\
\hline Kerala & 0.15 & 0.12 & $1.703^{*}$ & 0.022 & 0.018 \\
\hline MP & 0.24 & 0.30 & $-2.973^{* *}$ & 0.018 & 0.014 \\
\hline Maharashtra & 0.21 & 0.23 & -0.912 & 0.016 & 0.015 \\
\hline Orissa & 0.49 & 0.50 & -0.482 & 0.016 & 0.0157 \\
\hline Punjab & 0.06 & 0.10 & $-2.557^{*}$ & 0.03 & 0.0129 \\
\hline Rajasthan & 0.18 & 0.22 & $-2.497^{*}$ & 0.02 & 0.015 \\
\hline Tamil Nadu & 0.19 & 0.24 & $-2.872^{* *}$ & 0.0089 & 0.013 \\
\hline UP & 0.26 & 0.33 & $-5.971^{* *}$ & 0.0139 & 0.015 \\
\hline WB & 0.26 & 0.35 & $-5.138^{* *}$ & 0.0198 & 0.0155 \\
\hline
\end{tabular}

Note. A household is considered to be poor if its average per capita monthly expenditure (APCE) is less than the state poverty line in 1995.

Poverty likelihood is then calculated as the simple proportion of total households living with/without elderly of different categories $60+, 65+$ and $75+$. We also compute the corresponding t-statistics for comparison of the proportions of households with and without elderly. 